\title{
Ecology, Economy and Social Transformation among Marginalised communities: a Study of Muslim Fishermen in Barak Valley, Assam
}

\author{
Humayun Bokth, \\ Associate Professor, Department of Sociology, Assam University, Silchar, Assam, INDIA, PIN- 788011,
}

\begin{abstract}
Ecoology of a region plays important role in determining socio-cultural life of an individual or a community. Though influence of ecology on society was not given importance by the pioneer sociologists and social anthropologists but while conducting community study in India and abroad many ecologists and sociologists find close proximity between ecology and society. Linkage of society or community with ecology is found inseparable in a recent study conducted on Muslim fishermen in Barak Valley region of Assam. The present research article highlights how socio-economic life of Muslim fishermen community is influenced by the habitat they live in.
\end{abstract}

Keywords: Ecology, economy, fishermen community, inequality, marginalisation, caste heirarchy and Social status.

\section{Introduction}

The Muslim fishermen or Mahimals, as they are known locally, is a marginalised community living mainly in the Barak Valley region of Assam in Indian Union. The neighbouring Sylhet district of Bangladesh has traditionally been the stronghold of this community. The ecological setting of both the Barak valley part of Indian as well as Sylhet part of Bangladesh had traditionally been conducive for sustenance on fishing and cultivation of specific type of crops on low lying water logged areas. In course of time due to population pressure and commertialisation of agriculture the ecological setting got disturbed and at present for the Muslim fishermen of our study area fishing is hardly a main occupation. The fishermen of today are only fishermen in terms of their traditional association of fishing as an occupation. In day to day economic activities we find them engaged in diverse occupations. There has occured a social transformation among the community which is leading to continuous marginalisation of it in the regional society.

\section{Theoritical Background}

As an emerging sub-discipline of sociology social ecology takes into account the interdependence of the biophysical and socio-cultural domains in sociological enquiry. The studies of interactions between human beings and nature by renowned anthropologists like Marcel Mauss (1905), E.E. Evans Pritchard (1956), Raymond Firth (1959), Fredric Barthu (1964) and others strongly testify to the continuing vitality of ecological traditions. Varrier Elwin's monographs of Baiga (1939) and Agraria (1942) clearly demonstrate the impact of ecology on socio-cultural life of tribals in India. Indian pioneer in social ecology, Radhakamal Mukherjee (1930) expresses the relationship between nature and culture as both interactive and dynamic.

\section{Methodology}

The study is descriptive and qualitative in nature having some quantitative components. Both primary and secondary data are used for the study. Our primary data regarding the socio-economic condition of the Mahimal community is based on field work carried out in six villages of the three districts of Cachar, Karimganj and Hailakandi in the Barak-Valley region of South Assam. We selected 2 (two) villages from each of these districts. Total 300 respondents of Muslim fishermen community have been randomly selected for the study. Observation and interview schedule are tools used for data collection.

Ecology of Barak Valley: Barak Valley region in ancient period was the homeland of tribal people. According to historians, Austric speaking people belonging to the Proto-Australoid racial type, popularly known as the Nishadas were perhaps the first settlers in the plains and swampy low-land of the Sylhet including Barak-Valley and other parts of Eastern Bengal region. These early settlers, though introduced primitive agriculture in the region, some among them remained dependent on food gathering, hunting and fishing. When the catch of fish was huge they learnt the practice of converting it into dry fish. These early tribal groups were having their settlements at particular terminal localities and each tribe fiercely guarded their self-identity by imposing restrictions in intercourse with other such groups. In course of time the region developed into a settlement 
populated by bengalis who migrated from surrounding localities of East Bengal and they at present constitute the majority of the population of the region. Fishing and boating communities like Kaibartta, Patni, Namasudra and Muslim fishermen or Mahimals also migrated in this region due to ecological advantage.

In the past the hills surrounding the valley on three sides were densely forested and the valley of Barak was dotted with hollows, beels and swamps. These beels and haors were reservoir of palatable fish. A mention of these water-bodies is found in the account of William Hunter who mentioned in details the Chatla Fen in Cachar district which was about 12 miles in length and two miles in breadth at the widest part. Besides the Chatla fen he mentioned the names of some other important marshes, viz. Bakri haor, area 10 square miles; Bowalia, 6 square miles, Dubri beel, 1 square miles, Koya, 1 square mile, Karkaria beel, $1 / 2$ square mile, Thaphani beel, 4 square miles. In addition to the ones mentioned above, there were the following large beels in the than Hailakandi sub-division - Bawa, 2 square miles, Chungul, 2 square miles, Kuliala, 1 square mile, Chunati, $1 / 2$ square mile. Inspite of the process of silting up during all these years, some of these beels and haors continue to exist in reduced area at present and these are the water bodies around which most of the settlements of Muslim fishermen are located.

A special form of religious ceremony known as Nauka Puja (worship of boat) is still performed in the Surma-Barak Valley region by Hindu fishermen castes like Kaibartas and others. This event according to the researchers is indicative of participation of people of the region in sea voyages in the past for trade and commerce in which the people from lower castes were recruited as crew and helpers and among them this religious ceremony continues to exist till date whereby they worship various Gods and Goddesses, particularly Goddess Manasa. One of the important Geographical reason for the prevalence of this religious ceremony may be the assumption of the historians that once upon a time the Bay of Bengal extended upto Sylhet region - "It is, however, cerain that in ancient times a large part of Srihatta was included in a large sea, in all probability the Bay of Bengal. In Cachar, Karimganj and Sylhet districts there are large lakes that are locally called haor which is believed to be a corruption of sagar (or sea). Huen Tsang ( $7^{\text {th }}$ century AD) described Sylhet as Shih-li-cha-talo which was to the north east of Samatata among the hills near the sea.

At present the ecological set up of Barak valley is gradually losing its past heritage. The forest and water bodies like beels and haors are getting reduced day by day. Even the depth of major rivers of the region viz Barak, Kushiara, Sonai, Ghagra, Longai, Chiri and other rivers are getting reduced gradually. The swamp land is getting filled with humus and turning into raised land favourable for agricultural activities. It is important to mention that no adequate measures are taken by government to make the region adaptive to the changing ecological situation. Almost every year the low land of the region is logged with river water for which farmers cannot grow peddy on time. Majority of the farmers and fishing communities of the region are poor due unfavourable ecological condition.

Muslim Fishermen in Barak Valley: The Muslim fishermen or Mahimal is a distinct community among Muslims who lives mainly in the Barak-Valley of Assam and Sylhet district of Bangladesh. Fishing is the traditional occupation of the community. Before the advent of the Islam in the region, a bulk of population of this region had been fishermen by profession. They were looked down upon by the caste Hindus and regarded as untouchables and outcastes. When Hajarat Shah Jalal invaded Sylhet in 1328 (actually 1303 AD), a large scale conversion followed. The oppressed and downtrodden amongst the Hindus fell inspired by the egalitarian philosophy of the new religion. A bulk of the fishermen community embraced Islam in the wake of the new socio-political movements in the hope that the new faith would provide them with social-justice. Those converted formed the present day "Mahimal" community. Those amongst them remained within the fold of Hinduism, now form the bulk of Scheduled Caste communities of the region like the Kaivartas, Patnis, Namasudras and the others.

Mahimals had a tendency to live as a majority either in an isolated village or in a cluster of villages, which was because of ecological factor resulting out of traditional occupation of fishing compelling them to live near water-bodies like rivers, Khals, beels and haors, the locations which till recently or even today lack road or surface communication facilities for a part of the year due to water logging Therefore, the Mahimal populated villages in most cases are located near water-ways or water-bodies while the non-Mahimal populated villages are located often at a distance on raised land. Even in mixed population villages, the portion of villages where the Mahimals live are near the river or low lying areas of the village.

Mahimals occupy a marginal position in the regional Muslim society of Barak Valley. In fact the history of the entire region and beyond, including entire Eastern Bengal was the history of marginalisation of this group of people when in distant past these people were undergoing a shift in occupation from traditional fishing and fish business to the occupation of cultivation, by establishing their settlements near large water bodies much away from the villages established by other groups on raised and fertile land. Subsequently, in the land system that developed in the region during the medieval and colonial period there emerged a group of landed aristocracy possessing various titles and claiming an Ashraf (upper caste) status. The Mahimals, being 
tenants of inferior rights or small peasant proprietors in water-logged far-away places could not claim a higher status. Their traditional occupation placed them in a disadvantageous position. They continue to suffer from many disabilities inherent in the Hindu caste system even after conversion to Islam.

Economically, the community is the most backward, a majority of them are agriculturist, alongwith which they practice their traditional occupation of fishing. However, they being the inhabitants of low-lying areas, there is destruction of crop by frequent flood, as such agriculture as an occupation is not sufficient for sustenance. Fishing has also become less yielding because of changes in the environment and gradual loss of water-bodies. Hence, a large section of the Muslim fishermen or Mahimals has turned into wage-labour, hawkers of vegetable and other goods, sellers of fish imported from other states, rickshaw pullers, petty traders and employees in private companies as manual workers etc. There is also small emerging middle class, mostly consisting of school teachers, a few lawyers, grade - III and IV employees, which is still village based.

The physical features of the villages are having their impact on the social, cultural, economic and political life of the Muslim fishing community. It can be said that the remote inaccessible nature of the Mahimal inhabited villages has been responsible for social and cultural insularity of the group and thereby they remained as a distinct identifiable group within the regional Muslim society till today, though this insularity due to physical isolation is gradually disappearing as a result of ecological change, resulting in the disappearance of large waer-bodies due to population pressure and subsequent extension of agricultural activities. Moreover, implementation of various rural development schemes led to construction of roads and bridges connecting so far inaccessible areas with the outside world. All these have an impact in the context of social change among the community of Mahimals under our investigation.

\section{Field setting}

Social status of Muslim fishermen community in terms of their occupational, economic and educational attainment is analysed in the following tables. Socio-economic condition of the traditional Muslim fishermen community is found from secondary sources. Influence of ecology on socio-cultural life of the community is found by comparing their past and present socio-economic condition. The following tables highlight the contemporary occupational, economic and educational status of Muslim fishermen living at present in Barak Valley region.

Table - I.1 Distribution of heads of households according to occupational categories.

\begin{tabular}{|c|c|c|c|c|c|c|c|}
\hline \multirow[b]{2}{*}{$\begin{array}{l}\text { Sl. } \\
\text { No. }\end{array}$} & \multicolumn{2}{|c|}{ Occupational Categories } & \multicolumn{3}{|c|}{ Number of Respondents 'District wise' } & \multirow[b]{2}{*}{ Total } & \multirow[b]{2}{*}{$\begin{array}{c}\text { Percen- } \\
\text { tage }\end{array}$} \\
\hline & $\begin{array}{c}\text { Main } \\
\text { occupation }\end{array}$ & Subsidiary Occupation & $\begin{array}{l}\text { Cachar } \\
\text { District }\end{array}$ & $\begin{array}{c}\text { Karimganj } \\
\text { District }\end{array}$ & $\begin{array}{l}\text { Hailakandi } \\
\text { District }\end{array}$ & & \\
\hline 1 & Agriculture & $\begin{array}{ll}\text { Fishing/ wage labour/ } \\
\text { Business/ } & \text { Self-employed/ } \\
\text { services } & \end{array}$ & 20 & 18 & 20 & 58 & 19.33 \\
\hline 2 & Fishing & $\begin{array}{l}\text { Agriculture/ Wage labour/ } \\
\text { Boatman }\end{array}$ & 12 & 06 & 13 & 31 & 10.33 \\
\hline 4 & Wage labour & Nil & 30 & 30 & 22 & 82 & 27.34 \\
\hline 5 & Govt. Service & Agril & 01 & 01 & 01 & 03 & 1.00 \\
\hline 6 & Business & Agril & 04 & 06 & 04 & 14 & 4.67 \\
\hline 7 & Private Job & Agril & 04 & 05 & 04 & 13 & 4.34 \\
\hline 8 & Self-employed & Nil & 01 & 03 & 06 & 10 & 3.33 \\
\hline 9 & Fish Business & Agril & 04 & 08 & 04 & 16 & 5.33 \\
\hline
\end{tabular}

Source : Field work carried out during 2009-11.

It is observed from table I.1, that $19 \%$ of the respondents are having agriculture as their main occupation. However, they combine agriculture with fishing, wage labour, Business, self-employment or services of various types as subsidiary occupation. Inspite of the fact that most of the respondents are inhabitants of rural areas they could not depend solely on agriculture as an occupation because of the ecological condition of their habitation. Allmost all the villages under study are located near water-bodies like rivers, channels, Beels and haors and therefore highly prone to periodic flood. Next comes those $10 \%$ respondents who are till now engaged in fishing as a main occupation supplemented by agriculture or wage labour or boating. About $48 \%$ respondents are wage labour either having subsidiary occupation like seasonal agriculture or fishing or without any subsidiary occupation being purely dependent on wage labour as an occupation. Only $1 \%$ respondents are found to be engaged in Govt. service and all most all of them are either L. P. school teachers of the village school or Grade - III or Grade - IV employees. It is found that $4.67 \%$ of the respondents are engaged in business, mostly petty business. Whereas $4.34 \%$ of the respondents are engaged in Private jobs as security guards in Metros like Bangalore, Mumbai and Hyderabad and a few also as manual workers in West Asian 
countries. Self-employed constitute $3.33 \%$ of the respondents who are mainly owners of Rickshaws, Thelas or Maker of Mats etc. Around 5.33\% of the respondents are engaged in fish business either as growers and sellers of fish-seeds or whole sellers of Andhra and Kanpuri fishes imported from outside the state, whereas a few are engaged in purchasing of local fish from the fishermen of different localities and selling it in the market, locally known chuwari business. Lastly, a significant section i.e. $4 \%$ of the respondents is found as destitute who are without any gainful employment or source of earning being dependent on begging.

Table I.2

Economic profile of sample household in terms of monthly income

\begin{tabular}{|l|l|c|c|}
\hline SI No. & \multicolumn{1}{|c|}{ Monthly Income } & Number of Household & Percentage \\
\hline 1 & Upto Rs. 3000/- & 185 & 61.67 \\
\hline 2 & Rs. 3001/- to Rs. 5000/- & 48 & 16 \\
\hline 3 & Rs. 5001 to Rs. 7000/- & 24 & 8 \\
\hline 4 & Rs. 7001/- to Rs. 9000/- & 18 & 6 \\
\hline 5 & Rs. 9001/- to Rs. 11000/- & 15 & 5 \\
\hline 6 & Rs. 11001/- and above & 10 & 3.33 \\
\hline & & 300 & 100 \\
\hline
\end{tabular}

Source : Field work carried out during 2009-2011.

It is observed from the table - I.2 that $62 \%$ of the households are having a monthly income upto Rs. $3000 /-$ Whereas $30 \%$ of the households are having an income between Rs. 3001/- to Rs. 9000/- per month. Only $5 \%$ of the sample households are having monthly income within Rs. 9001/- to Rs. 11,000/-, whereas 3\% of the sample households are having monthly income above Rs. 11, 0001/-.

Now the following table brings out the educational profile of the population of sample household.

Table $-\mathbf{I . 3}$

Educational profile of population of sample household

\begin{tabular}{|l|l|c|c|}
\hline Sl. No. & \multicolumn{1}{|c|}{ Level of Education } & Number of persons & Percentage \\
\hline 1 & Illiterate & 580 & 29.74 \\
\hline 2 & Pre-school & 351 & 18 \\
\hline 3 & Lower-Primary & 388 & 19.90 \\
\hline 4 & Middle-English School & 245 & 12.56 \\
\hline 5 & Class - IX & 215 & 11.02 \\
\hline 6 & Class - X/ HSLC Passed & 130 & 6.67 \\
\hline 7 & Class - XI-XII/H.S. Passed & 23 & 1.18 \\
\hline 8 & Graduate & 10 & 0.52 \\
\hline 9 & Post-graduate & 05 & 0.26 \\
\hline 10 & Others & 03 & 0.15 \\
\hline & & $\mathbf{1 9 5 0}$ & $\mathbf{1 0 0}$ \\
\hline
\end{tabular}

\section{Source : Field work carried during 2009-2011.}

It is observed from the table - I.3 that about $29.74 \%$ or one third of the population of the sample households are illiterate. $18 \%$ of the population of the sample households is at pre-school stage. Those who are literate, $19.90 \%$ either got primary school education or attending primary school, $12.56 \%$ are either educated up to middle school level or attending M.E. Schools and another $11.02 \%$ are either attending classes upto - IX or passed IX th standard. Further only $6.67 \%$ of the population of the sample households of Mahimals are high school final passed or will be appearing in the school final examination and $1.18 \%$ are in classes XI or XII or passed the Higher Secondary School examination. Only $0.52 \%$ of the Mahimal population of the sample household is graduates and the post-graduates constitute a negligible percentage $(0.26 \%)$. In other category like ITI trade certificates holders, polytechnic diploma holders constitute only $0.15 \%$ of the population of sample household of Mahimal community.

From an analysis of the above tables and secondary data we can conclude that the Mahimals or Muslim fishermen of Barak Valley districts of Cachar, Karimganj and Hailakandi are predominantly a rural community. Agriculture alongwith fishing has been their traditional occupation. However, due to ecological reason now a significant section of this community is adopting wage labour as their main occupation. There is also a trend among them to engage in diverse occupation. The level of income is very low among them, a majority (78\%) of them are having an average monthly income upto Rs. 5000 only. Educationally also the community in the study area are found as backward, particularly in terms of secondary and higher education. Illiterates constitute $1 / 3^{\text {rd }}$ of the total persons covered under household survey. 


\section{Conclusion}

To conclude, our finding have shown that the Mahimals as a community is undergoing a process of transition from a fishing cum agricultural community to a community whose principal means of living is wage labour with subsidiary activities like fishing, agriculture \& petty business. Islamisation as a process of social change has not led to the integration of the community with other Muslim social groups of the region into an Islamic Ummah. Rather Mahimals exist as a separate social category even among their co-religionists. Social mobility through Islamisation also could not become a mass phenomenon among them. Only the process of politicisation is having some noticeable impact in the socio-cultural \& political-economic life of the Mahimals as we have found from our study. Social change among them, it seems, in contemporary period is mainly because of changes in the economy and politicisation of caste and similar identities.

\section{References}

[1]. Guha Ramchandra, (2008), Social Ecology,Oxford University Press, New Delhi

[2]. Choudhury, M.A. (1997), "Sylheter Rajnaitik Itihas: Prachinkal Theke 1857" (in Bengali) in M. Abdul Aziz, M. Habibur Rahman et.al. (ed.), Brihattar Syleter Itihas (in Bengali) (History of Greater Sylhet), Brihattar Sylhet Itihas Pranayan Parishad, Sylhet, Bangladesh, pp-29-71.

[3]. Allen, B. C. (1905), Assam District Gazetteers, Vol I, Cachar, Baptist Mission Press, Calcutta.

[4]. Bhattacharjee, Amalendu. (1995), "Surma-Barak Upatayakar Naukapuja" (in Bengali) in A. K. Dutta (ed), Sribhumi Srihatta (in Bengali), Durgapur Srihatta Sammilani, Durgapur, pp-184-211.

[5]. Bhattacharjee, J.B, (1991), Social and Polity Formations in Pre-colonial North East India: The Barak Valley Experience, Haranad Publication and Vikas, New Delhi.

[6]. Haque, Anwarul (1985) "Mahimal”; The Muslim Fishermen Community of Barak Valley, Assam, Nikhil Cachar and Karimganj Muslim Fishermen Federation, Karimganj.

[7]. Akbar, Harun. (1994), Avijattya Sylheti Somaj (in Bengali), Kafila Prokashani, Sylhet, Bangladesh.

[8]. Ahmad, Fayez Uddin, (1985), Ami Amar Samajer Janyo Ki Kariyachi (in Bengali), F. U. Ahmed, Tinghari, Bihara, Cachar.

[9]. Basu, Sib Tapan, (2004), Barak Upataykar Muslim Samaj (in Bengali), Golam Mohd. Sappu, Karimganj.

[10]. Rahman, Ashadur, (2004), Muslim Samaj : Kichu Samasya-O-Samadhan (in Bengali), J. K. Group, Badarpur, Karimganj. 